\title{
DECOMPOSITION OF THE RUBBER TREE Hevea brasiliensis LITTER AT TWO DEPTHS
}

\author{
Thiago Claudino Gréggio ${ }^{1}$, Luiz Carlos Assis ${ }^{1}$, and Ely Nahas ${ }^{1 *}$
}

\begin{abstract}
A B S T R A C T
The decomposition of soil litter contributes to maintaining agricultural sustainability, since the nutrients released by microbial activity are determinants of the net productivity of the agroecosystem. The decomposition of rubber tree (Hevea brasiliensis [Willd. ex A. Juss.] Müll. Arg.) leaves located on the surface and buried in at $10 \mathrm{~cm}$ depth in Forest and Savannah (Cerradão) soils (Oxisols) was studied, with emphasis on the production of $\mathrm{CO}_{2}$ and the monthly variation of the remaining amounts of litter mass, soluble substances, cellulose and lignin. To evaluate $\mathrm{CO}_{2}$ production, $H$. brasiliensis leaves were incubated for 30 days in soils from the $0-2 \mathrm{~cm}$ and $10-12 \mathrm{~cm}$ layers. $\mathrm{CO}_{2}$ production increased in the $0-2 \mathrm{~cm}$ layer in comparison to the 10 $12 \mathrm{~cm}$ layer. Litter mass and soluble substance loss was of 62 and $72 \%$ at the end of nine months of incubation, and of 38 and $65 \%$, respectively, in the first three months, being greater in the deeper (71$74 \%)$ than in surface layer (48-55\%). Forest soil stimulated more litter mass loss and cellulose decomposition (only in the surface layer) than Savannah soil. The cellulose (25\%) content decreased and lignin $(30 \%)$ increased in the initial months of incubation, however, at the end of the period of this study the same content (29\%) was found.
\end{abstract}

Key words: litter mass, cellulose, lignin, soluble substances, litter-bags.

\section{INTRODUCTION}

Maintenance of a forest ecosystem depends on the soil physical-chemical properties and its interaction with the biotic communities that act, on different temporal and spatial scales, in cycling of organic material (OM), consequently providing the nutrients necessary for this system (Beare et al., 1995). The greater source of residues comes from the OM decomposition of leaf litter that is accumulated on the surface of the soil, and the dead roots of the plants (Chadwick et al., 1998; Fioretto et al., 2001; Santa Regina and Tarazona, 2001).

Among the decomposing agents, bacteria and fungus have a preponderant role due to their greater biomass and respiratory metabolism (Torres et al., 2005). Due to heat, moisture and the action of decomposing agents, the chemical elements contained in the litter mass are mobilized and re-absorbed by the roots, giving rise to a new plant cycle and ensuring conditions of permanence of the system (Guo and Sims, 1999), even when soils are considered to have low fertility.

Many models of degradation of vegetal residues consider the quality of the residue (Sall et al., 2006), biotic and abiotic factors (Mamilov and Dilly, 2002) and the climate (Virzo of Santo et al., 1993; Salamanca et al., 2003) as factors that influence the rate of decomposition and mobilization of nutrients. Thus, the degradation of the leaves of several plants contained in litter-bags has shown a better correlation to temperature than to soil moisture (Isaac and Nair,

\footnotetext{
${ }^{1}$ Universidade Estadual Paulista, Facultad of Ciencias Agrarias y Veterinarias (FCAV/UNESP), Departamento of Produção Vegetal, 14884-900 Jaboticabal, São Paulo, Brasil.

E-mail: enahas@fcav.unesp.br *Corresponding author.

Received: 11 June $2007 . \quad$ Accepted: 8 November 2007.
} 
2005). Residues with low quantities of lignin and C/ $\mathrm{N}$ ratio presented the fastest rate of mass loss and nutrients release (Wedderburn and Carter, 1999). Of the abiotic factors, OM content and soil fertility are the factors that influenced composition and activity of the soil microbial community (Rigobelo and Nahas, 2004). Consequently, soils with different chemical compositions can influence mineralization rate of vegetal residues.

A set of variables have been used to evaluate the decomposition of organic residues deposited in the soil, which includes the mass loss of plant litter and the determination of the quantities of the main components like soluble substances (Berg and Tamm, 1991), cellulose and lignin (Lähdesmäki and Piispanen, 1988; Donnelly et al., 1990; Johansson et al., 1995; Wedderburn and Carter, 1999; Berg, 2000). As well, the rate of decomposition in Pinus sylvestris L. was evaluated through mass loss and $\mathrm{CO}_{2}$ production (Chadwick et al., 1998).

The majority of studies related to the litter decomposition have been carried out using several plant species (Virzo de Santo et al., 1993; Briones and Ineson, 1996; Berg, 2000; Fioretto et al., 2001; Salamanca et al., 2003; Waldrop et al., 2004; Costa et al., 2005; Isaac and Nair, 2005), but there is little information in relation to the rubber tree. $H$. brasiliensis is a Euphorbiaceae, native from Amazonia and common in the primary forest. It is of high economic value due to latex yields for rubber production. It is difficult to manage, produces a litter mass with a fine layer and has leaves with a high nutrient content (Silva et al., 1998). The initial C/N ratio of the litter of the rubber tree is 23 , and can be considered low (Höfer et al., 2000).

The objective of the present study was to evaluate monthly, from October 2004 to June 2005, the decomposition of rubber tree leaves placed on the surface and at a depth of $10 \mathrm{~cm}$ in Forest and Savannah soils.

\section{MATERIALS AND METHODS}

The study was carried out in 2004-2005, in two forest reserves of Jaboticabal, Sao Paulo, Brazil, approximately 20 kilometers apart. One is located at the Faculty of Agrarian and Veterinary Sciences of the Universidade Estadual Paulista (FCAV/UNESP) $\left(21^{\circ} 05^{\prime} \mathrm{S}, 48^{\circ} 10^{\prime} \mathrm{W}, 560\right.$ m.o.s.1.) and the other at the Recreio farm ( $21^{\circ} 17^{\prime} \mathrm{S}, 48^{\circ} 22^{\prime} \mathrm{W}, 630$ m.o.s.l.). The vegetation in the UNESP reserve is classified as semideciduous tropical broadleaved forest (termed Forest in this study), and that of the Recreio farm is classified as semideciduous broadleaved tropical forest, with characteristics of transition toward savannah (termed Savannah), and is characterized by three levels of vegetation, with umbrophylic species, creepers and of low height in the first level, bushes and small arboreal forms with a height of 5 to $6 \mathrm{~m}$ in the second level and, finally, trees of 10 to $20 \mathrm{~m}$ high and less winding trunks in the third level. A central area of each site was demarked, fenced off and divided into 63 plots of approximately $3 \times 2 \mathrm{~m}$. Both soils were classified as Oxisols according to the USDA Soil Taxonomy (USDA, 1975) and had the chemical composition and granulometrics described in Table 1.

The rubber leaves were collected from the trees in a state of senescence, which is with opaque coloring in comparison to the others. The leaves were washed carefully in water, brushed lightly and dried in forced ventilation ovens at $45{ }^{\circ} \mathrm{C}$ for $72 \mathrm{~h}$. Then $5 \mathrm{~g}$ (dry weight) of leaves were placed in litter-bags, with a total of 252 bags (four per plot). The litter-bags, with a size of $10 \times 15 \mathrm{~cm}$, were made with $0.28 \times 0.78 \mathrm{~mm}^{2}$ (mesh 50) high density mono-filament polyethylene, that avoid insects to pass through. After the removal

Table 1. Chemical and granulometry composition of Forest and Savannah soils.

\begin{tabular}{|c|c|c|c|c|c|c|c|c|c|c|c|c|}
\hline \multirow[t]{2}{*}{ Soil } & DSS & \multirow[t]{2}{*}{ pH } & \multirow{2}{*}{$\frac{\text { OM }}{\%}$} & \multirow{2}{*}{$\begin{array}{c}\mathbf{P} \\
\mathrm{mg} \mathrm{dm^{-3 }}\end{array}$} & $\mathbf{K}$ & $\mathrm{Ca}$ & Mg & $\mathbf{H}+\mathbf{A l}$ & Clay & Lime & $\begin{array}{l}\text { Fine } \\
\text { sand }\end{array}$ & $\begin{array}{c}\text { Heavy } \\
\text { sand }\end{array}$ \\
\hline & $\mathrm{cm}$ & & & & \multicolumn{4}{|c|}{$\mathrm{mmol} \mathrm{dm}{ }^{-3}$} & \multicolumn{4}{|c|}{$\mathrm{g} \mathrm{kg}^{-1}$} \\
\hline \multirow[t]{2}{*}{ Forest } & $0-2$ & 6.1 & 6.6 & 21 & 6.3 & 89 & 27 & 20 & 550 & 280 & 100 & 70 \\
\hline & $10-12$ & 5.6 & 7.0 & 8 & 6.1 & 45 & 22 & 25 & 620 & 230 & 80 & 70 \\
\hline \multirow[t]{2}{*}{ Savannah } & $0-2$ & 4.5 & 8.4 & 20 & 4.9 & 11 & 8 & 47 & 220 & 10 & 260 & 510 \\
\hline & $10-12$ & 4.3 & 8.7 & 9 & 1.7 & 8 & 5 & 52 & 270 & 20 & 270 & 440 \\
\hline
\end{tabular}

DSS: depth of soil sample; $\mathrm{pH}$ in $\mathrm{CaCl}_{2}$; $\mathrm{OM}$ : organic material; $\mathrm{H}+\mathrm{Al}$ : potential acidity. 
of the surface litter from soil, the litter-bags were buried at $10 \mathrm{~cm}$ depth and others were placed on the soil surface. Monthly and for 9 months, 14 litter-bags were collected from each position, seven from the surface and seven from the $10 \mathrm{~cm}$ depth. The collected litter-bags were dried at $75^{\circ} \mathrm{C}$ for 3 days, cleaned with aid of a brush to remove adhering soil and then weighed. The decomposition rate was evaluated by weight loss.

The leaves removed from the litter-bags were grounded and sifted $(<0.7 \mathrm{~mm})$. To determine the quantity of soluble substances in hot water (carbohydrates, proteins and other soluble compounds in hot water), $0.5 \mathrm{~g}$ (dry weight) of leaves were placed in a crucible with a $\mathrm{N}^{\circ} 2$ porous plate, and this in a beaker. Fifty milliliters of distilled water was added and boiled gently for $1 \mathrm{~h}$ (Summerel and Burgess, 1989). The liquid was removed by vacuum pump, the leaves were rinsed twice in cold water and dried at 75 ${ }^{\circ} \mathrm{C}$ for $18 \mathrm{~h}$ and weighed. Weight loss was defined as soluble substances in hot water.

Respiratory activity was determined using soil samples collected at the two depths, $0-2 \mathrm{~cm}$ and $10-12 \mathrm{~cm}$ from each plot (Rezende et al., 2004). A quantity of $0.5 \mathrm{~g}$ (dry weight) of rubber tree leaves were added to 200 $\mathrm{g}$ of soil with the water content equilibrated at $60 \%$ of field capacity, and incubated for 30 days at $30^{\circ} \mathrm{C}$. The quantity of $\mathrm{CO}_{2}$ produced was determined daily for the first 10 days and then every 3 days. As control were prepared flasks with soil but without rubber tree leaves.

The quantities of lignin and cellulose were determined monthly by the Van Soest and Wine (1968) method, which were based on the separation of the different compounds of the material using specific reactives. The moisture content was determined after drying the soil at $105{ }^{\circ} \mathrm{C}$ for $24 \mathrm{~h}$ and the temperature was determined using a digital thermometer.

A completely random experimental design was used and the variance analysis was made using the program SAS (SAS Institute, 1990). The results in percentages were previously submitted to the normality test. The Tukey test $(p<0.05)$ was applied for comparison of the means of the experimental results.

\section{RESULTS AND DISCUSSION}

The respiratory activity resulting from the incubation of rubber tree leaves in Forest and Savannah soils from
0-2 cm (surface) and 10-12 cm depth (Figure 1) showed that the cumulative $\mathrm{CO}_{2}$ production observed at the end of the incubation period: 1) increased from 1.3 to 2.3 times in the surface soil compared to that from the 10-12 cm depth layer; 2) increased from 1.7 to 2.7 times with the incubation of rubber tree leaves in comparison to the control (without leaves); 3 ) was 1.1 to 1.2 times greater in the surface layer of the Forest soil than that of Savannah soil, but at the 10$12 \mathrm{~cm}$ depth layer, it was 1.1 to 1.2 times greater in the Savannah soil.

The factors that influenced the increased respiratory could have been the result of the better quality of soil at the surface in comparison to the that from 10-12 $\mathrm{cm}$ depth (Table 1) and of the leaves mineralization located in the soil. In accordance with Fernandes et al. (2005), the reduction of $\mathrm{CO}_{2}$ production with soil depth was due to more availability of OM in the soil surface. Organic material is a determining factor for

A
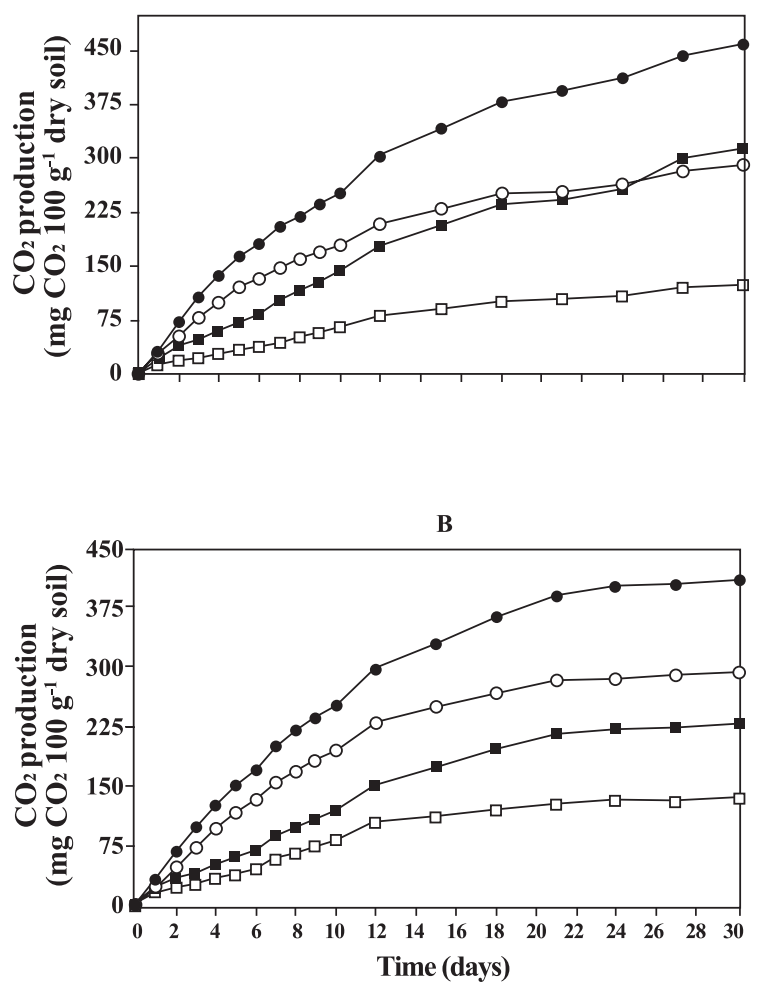

Figure 1. Cumulative microbial respiratory activity found from the incubation of Hevea brasiliensis leaves in the 0-2 cm ( $\square$ : with leaves; $\square$ : without leaves, control) and 10-12 cm depth ( $\bullet$ : with leaves; $O$ : without leaves) layers of Forest (A) and Savannah (B) soils. 
the microbial population growth and consequently the increase in respiratory activity. Thus, the reduction of nutrients and $\mathrm{OM}$ with the soil depth decreased $\mathrm{CO}_{2}$ production (Kurzatkowski et al., 2004). The second evidence suggests a direct effect of the $\mathrm{C}$ mineralization resulting from the addition of OM. The quantity of $\mathrm{CO}_{2}$ produced corresponds to the metabolism of 2.4 to $2.7 \mathrm{~g}$ of glucose $\mathrm{g}^{-1}$ of rubber tree leaves in $100 \mathrm{~g}$ of dry soil. This quantity of $\mathrm{C}$ and energy is used to provide microbial growth and the cycling of soil nutrients.

The third affirmation is consistent with the results, indicating that the quality of Forest soil from the higher layer is better than that of Savannah soil. However, the greater respiratory activity found in Savannah soil in comparison to Forest soil at the $10-12 \mathrm{~cm}$, can only be explained by the greater quantity of OM found in this study (Table 1).

After a 9 months period, the accumulated mass loss of $H$. brasiliensis leaves contained in the litter-bags was on an average of $62 \%$ (Figure 2A). Significant differences $(p<0.05)$ between the losses were found only in the first three months and were $38 \%$ of total losses. The temperature in this period decreased and the soil moisture increased significantly (Figure 3A, 3B). Consequently, these losses can be attributed to increased rainfall. This effect was observed by Virzo de Santo et al. (1993), who attributed the litter mass loss to the amount of rain in soil planted with different pine trees. Beginning in February the temperature and moisture of the soil decreased slightly until the end of the period of this study, which should have decreased mass loss of the leaves. As well, the increase in the recalcitrant components during this period could have limited the rate of decomposition. The litter mass loss has been found in similar assays to that conducted in this study, and is the result of the liberation of soluble and easily decomposable components (Musvoto et al., 2000). After 140 days, $14 \%$ of the mass of Vismia guianensis leaves was lost in three forest soils from central Amazonia (Kurzatkowski et al., 2004). A reduction of $30 \%$ of Jacarandá-da-Bahia (Dalbergia nigra (Vell.) Allemão ex Benth.) and Eucalyptus grandis W. Hill ex Maiden litter mass was found after four months in forest soil, and $40 \%$ after eight months in eucalyptus soil (Rezende et al., 2001).

Loss of litter mass in Forest soil was $55-74 \%$, while in Savannah soil was $48-71 \%(\mathrm{p}<0.05)$. This result can be attributed to soil moisture, which was 2.7 times

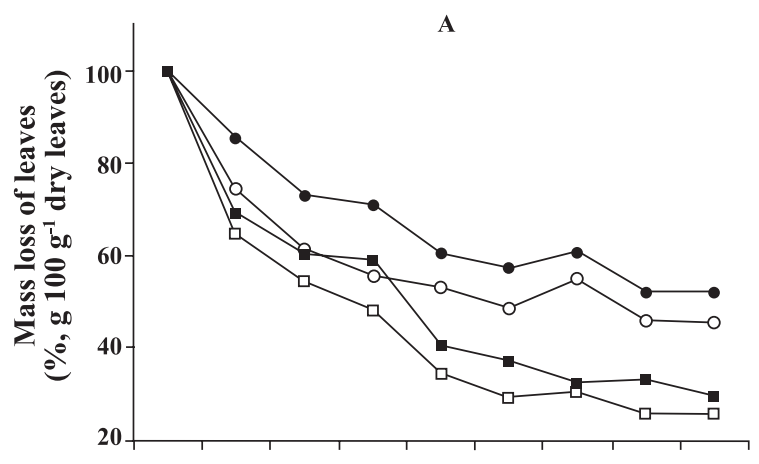

B

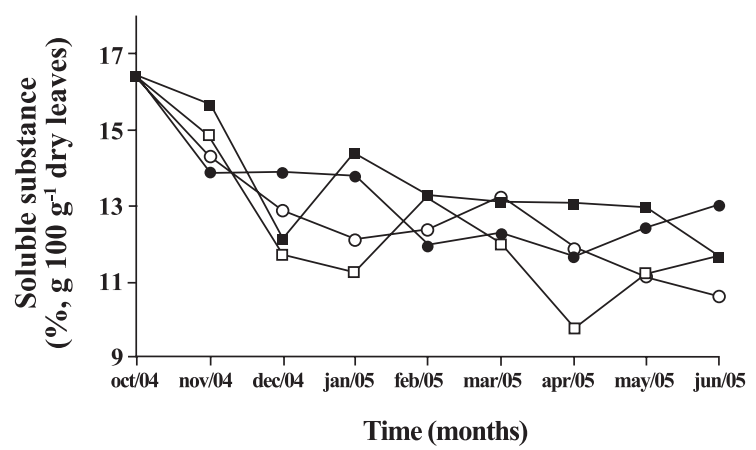

Figure 2. Mass loss (A) and soluble substance quantities (B) from Hevea brasiliensis leaves incubated in the surface and in $10 \mathrm{~cm}$ depth of Forest $(0: 0 \mathrm{~cm} ; \bullet: 10 \mathrm{~cm})$ and Savannah $(\square: 0$ cm; $\mathbf{~}: 10 \mathrm{~cm})$ soils.

higher in Forest soil than in Savannah soil (Figure $3 \mathrm{~B})$. Moisture is a determining factor in the decomposition of OM. Johansson et al. (1995) reported that the effect of moisture on the litter mass loss occurred mainly during the initial period of incubation of a pine forest soil. Accordingly, decomposition of two species of grasses was determined by soil moisture (Liu et al., 2006).

A significant effect $(p<0.05)$ of depth was found; thus the accumulated mass loss of the leaves buried at $10 \mathrm{~cm}$ of depth was 71 and $74 \%$, and at the surface it was 48 and 55\%, in the Savannah and Forest soils, respectively (Figure 2A). According to Fernandes et al. (2005) microbial biomass and respiratory activity decreased from the surface layer of the soil to the deeper layer. This decrease was is due to the effect of the vegetal cover on the soil structure and the OM accumulation (Fialho et al., 1991). The results obtained in this work suggest a contrary effect to those 
A

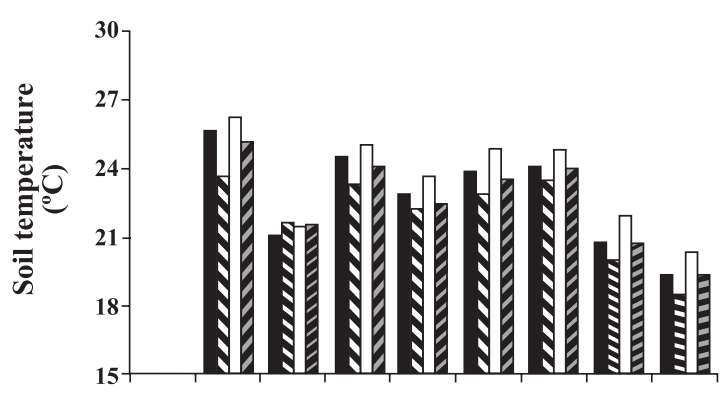

B

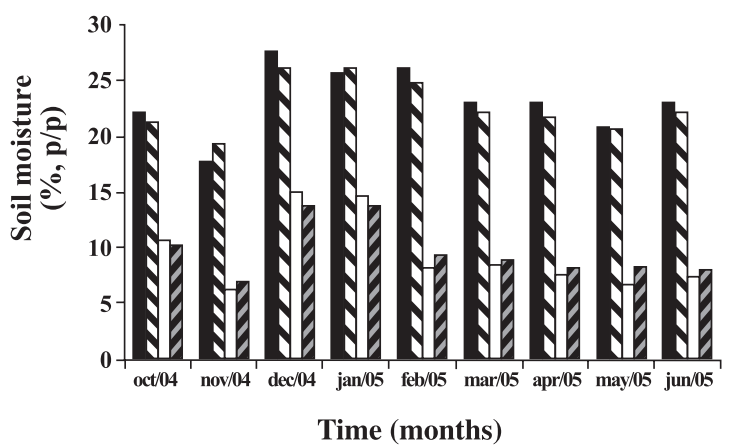

Figure 3. Temperature (A) and moisture (B) of the surface and $10 \mathrm{~cm}$ depth of Forest $(\square: 0 \mathrm{~cm}$; IIV : $10 \mathrm{~cm}$ ) and Savannah ( $\square: 0 \mathrm{~cm}$; VII : $10 \mathrm{~cm})$ soils.

studies. This is probably because the leaves located at the surface of soil are more exposed than the buried leaves to environmental variations, such as the effect of drying and temperature. As a result of environmental influence, the higher moisture content of the deeper layer of the soil favored the litter mass loss. Thus, after 26 months of incubation, Douglas et al. (1980) observed losses of $31 \%$ when wheat straw was placed (Triticum aestivum L.) on the surface, and of $85 \%$ at a depth of $15 \mathrm{~cm}$. Nevertheless, significant differences were found between the two soils at the surface layer (except October 2004, April and May, 2005) and at a depth of 10-12 cm in November and December 2004, and January 2005, indicating that the rate of decomposition was greater in Forest soil, probably favored by the better chemical composition than that found in the Savannah soil (Table 1).

The initial quantities (October 2004) of soluble substances found in the leaves decreased on average $23 \%$ up to December (Figure 2B). This rapid loss of soluble substances was due to the microbial decomposition and lixiviation of soluble foliar nutrients. As was observed in laboratory, lixiviation is more rapid in leaves after being dried and immersed in water than in leaves that were not dried. Schroth et al. (1992) reported that the losses were high during the first 11 days, especially N, P (50\%) and K (75$80 \%)$. In general, significant differences $(\mathrm{p}<0.05)$ among the quantities of soluble substances were not found due to the effect of the different soils and depth in which the leaves where placed (Figure 2B).

On average the initial amounts of cellulose of rubber tree leaves (October 2004) was equal to $25 \%$ of dry foliar weight (Figure 4A). These quantities decreased to $21 \%$ in December 2004 and later increased to $29 \%$ (June 2005), but in general, without significant differences among the quantities found in the different months. A significant effect of depth on the cellulose degradation was not verified, except in the months of January to June 2005, when the quantities of cellulose were greater in the buried leaves than in those placed on the surface, indicating that the decomposition of foliar cellulose was greater on the soil surface than in that buried. Analyzing the effect of the soil, it was verified that the percentage of cellulose was greater

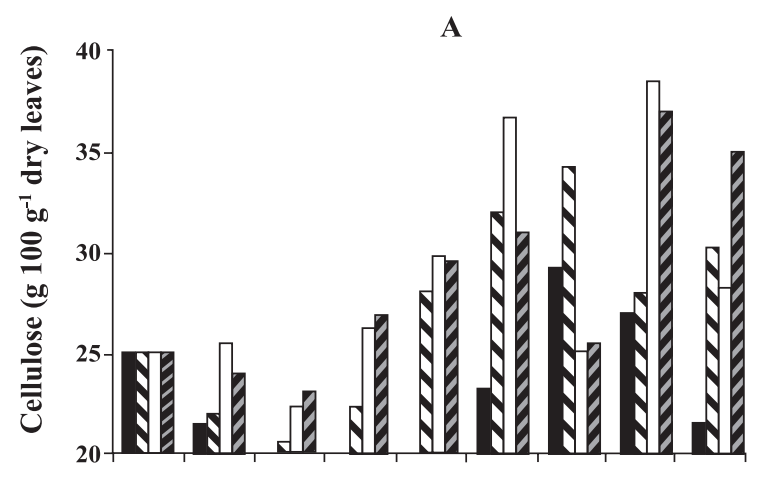

B

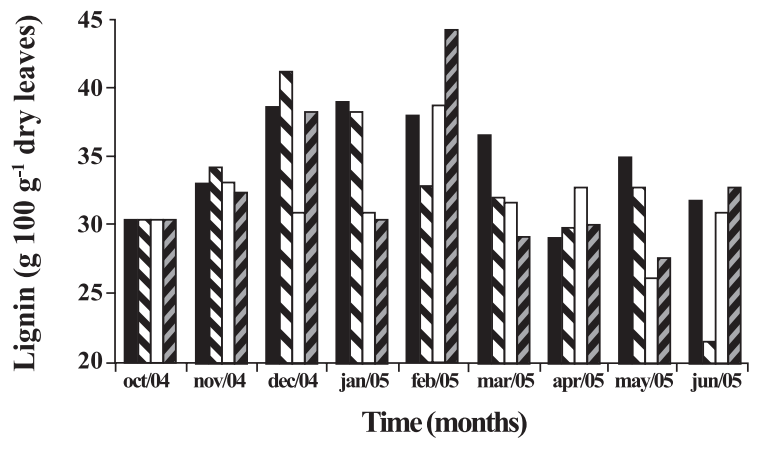

Figure 4. Residual cellulose (A) and lignin (B) from Hevea brasiliensis leaves incubated in the surface and at $10 \mathrm{~cm}$ depth of Forest (-: $0 \mathrm{~cm}$;MV: 10

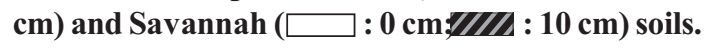


$(\mathrm{p}<0.05)$ among the leaves placed on the surface and in the 10-12 cm layer (only for the months of November, December and January) in the Savannah soil, indicating a higher rate of mineralization in Forest soil.

The quantity of lignin foliar found in October 2004 was $30 \%$ of the dry weight (Figure 4B). This quantity increased to $39-41 \%$ in December in the Forest soil and $39-44 \%$ in February in the Savannah soil, and later decreased until the end of the period of this study. In general, no effect of the depth or type of soil on the percentage of foliar lignin was verified.

It seems that while the quantity of soluble substances decreases rapidly, the quantity of cellulose and lignin remained relatively unaltered until the end of the study. This tendency has been confirmed in several studies. The rapid reduction of soluble substances and the slow reduction of cellulose and lignin, after 286 days, were also observed by Costa et al. (2005) in recently fallen leaves of E. grandis. While the quantities of cellulose and lignin remain relatively stable, starch, proteins, and sugars decrease rapidly during the decomposition of Picea abies (L.) H. Karst. and Populus tremula L. (Lähdesmäki and Piispanen, 1988). After 20 weeks, there was no significant reduction of lignin, but cellulose decreased, following a linear kinetic in the legume Inga spp. used in the agroforestry system (Leblanc et al., 2006).

The reduction of soluble substances probably increased the quantities of cellulose and lignin in the months of February-March. Soluble components are rapidly lost, followed by polysaccharides, cellulose, hemicellulose and, lastly, lignin (Wedderburn and Carter, 1999). Lignin is sufficiently resistant to decomposition and the increase in its concentration is due to the liberation of forms of $\mathrm{C}$ more soluble (Costa et al., 2005). High concentrations of cellulose and lignin, like those observed in this study, hinder the attack of decomposing microorganisms, reducing decomposition rate (Gallardo and Merino, 1993).

\section{CONCLUSIONS}

It was found in this study that the variation in the chemical composition of Forest and Savannah soils influences the rate of degradation of rubber tree leaves. The production of $\mathrm{CO}_{2}$ initially decreased with soil depth and with time, showing an exhausting of the substrate. During the 9-month period of incubation, the quantities of foliar mass and of soluble substances decreased significantly, while the quantities of cellulose and lignin remained relatively stable. This effect can be attributed more to the level of rainfall (which increases soil moisture) than the soil temperature. While the loss of litter mass increased with soil depth, possibly favored by the greater moisture content of the deeper layer, the quantity of cellulose decreased and the quantities of soluble substances and lignin remained unaltered. Forest soil influenced mass loss and decomposition of cellulose more than did Savannah soil.

\section{R E S U M E N}

Descomposición del mantillo del árbol del caucho Hevea brasiliensis en dos profundidades. Thiago Claudino Gréggio ${ }^{1}$, Luiz Carlos Assis ${ }^{1}$, and Ely

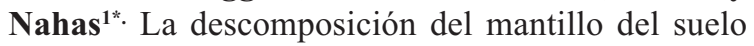
contribuye a mantener la sostenibilidad agrícola, puesto que los nutrientes liberados por la actividad microbiana son determinantes para la productividad del ecosistema. La descomposición de hojas del árbol del caucho (Hevea brasiliensis) [Willd. ex A. Juss.] Müll. Arg.) colocadas en la superficie y enterradas en la profundidad de $10 \mathrm{~cm}$ en suelos de Bosque y Cerradão (Oxisols) se estudió con énfasis en la producción de $\mathrm{CO}_{2}$ y la variación mensual de las cantidades remanentes de masa foliar (MF), substancias solubles (SS), celulosa y lignina. Para evaluar la producción de $\mathrm{CO}_{2}$ se incubaron hojas del $H$. brasiliensis por 30 días en suelos a profundidades 0-2 cm y 10-12 cm. La producción de $\mathrm{CO}_{2}$ aumentó en la capa superficial 0-2 cm con relación a la capa $10-12 \mathrm{~cm}$. La pérdida de MF y de SS fue de 62 y $72 \%$ al final de nueve meses de incubación, y de 38 y $65 \%$, respectivamente, los tres primeros meses, siendo mayor en la capa inferior (71-74\%) que en la superior (48-55\%). El suelo de Bosque estimuló más la pérdida de MF y descomposición de la celulosa (sólo en la capa superficial) que el de Cerradão. Las cantidades de celulosa (25\%) disminuyeron y las de lignina (30\%) aumentaron en los meses iniciales de incubación, pero al final del período en este estudio presentaron el mismo contenido $(29 \%)$.

Palabras clave: masa foliar, celulosa, lignina, substancias solubles, bolsas.

\section{ACKNOWLEDGEMENTS}

The authors are grateful for grants from the CNPq (Conselho Nacional de Desenvolvimento Científico e Tecnológico) and for the help of CAPES (Coordenação de Aperfeiçoamento de Pessoal em Nível Superior). 


\section{LITERATURE CITED}

Beare, M., H.O. Coleman, D.C. Crossley, D.A. Hendrix, and P.F. Odum. 1995. A hierarchical approach to evaluating the significance of soil biodiversity to biogeochemical cycling. Plant Soil 170:5-22.

Berg, B. 2000. Litter decomposition and organic matter turnover in northern forest soils. For. Ecol. Manage. 133:13-22.

Berg, B., and C.O. Tamm. 1991. Decomposition and nutrient dynamics of litter in long-term optimum nutrition experiments. I. Organic matter decomposition in Norway spruce (Picea abies) needle litter. Scand. J. For. Res. 6:305-321.

Briones, M.J.I., and P. Ineson. 1996. Decomposition of eucalyptus leaves in litter mixtures. Soil Biol. Biochem. 28:1381-1388.

Chadwick, D.R., P. Ineson, C. Woods, and T.G. Piearce. 1998. Decomposition of Pinus silvestris litter in litter bags: influence of underlying native litter layer. Soil Biol. Biochem. 30:47-55.

Costa, G.S., A.C. Gama-Rodrigues, and G.M. Cunha. 2005. Decomposition and nutrient release from leaf litter of Eucalyptus grandis in plantations and regrowth systems in northern Rio de Janeiro state, Brazil. Rev. Árvore 29:563-570.

Donnelly, P.K., J.A. Entry, D.L. Crawford, and K. Cromack Jr. 1990. Cellulose and lignin degradation in forest soils: Response to moisture, temperature and acidity. Microbiol. Ecol. 20:289-295.

Douglas, C.L., R.R. Allmaras, P.E. Rasmussen, R.E. Ramig, and N.C. Roager. 1980. Wheat straw composition and placement effects on decomposition in dryland agriculture of the Pacific Northwest. Soil Sci. Soc. Am. J. 44:833-837.

Fernandes, S.A.P., W. Bettiol, and C.C. Cerri. 2005. Effect of sewage sludge on microbial biomass, basal respiration, metabolic quotient and soil enzymatic activity. Appl. Soil Ecol. 30:65-77.

Fialho, J.F., A.C. Borges, e N.F. Barros. 1991. Cobertura vegetal e as características químicas e físicas e atividade da microbiota de um Latossolo VermelhoAmarelo distrófico. Rev. Bras. Ci. Solo 15:21-28.

Fioretto, A., S. Papa, G. Sorrentino, and A. Fuggi. 2001. Decomposition of Cistus incanus leaf litter in a Mediterranean maquis ecosystem: mass loss, microbial enzyme activities and nutrient changes. Soil Biol. Biochem. 33:311-321.

Gallardo, A., and J. Merino. 1993. Leaf decomposition in two Mediterranean ecosystems of Southeast Spain: influence of substrate quality. Ecology 74:721-727.

Guo, L.B., and R.E.H. Sims. 1999. Litter production and nutrient return in New Zealand eucalypt short-rotation forests: implications for land management. Agric. Ecosyst. Environ. 73:93-100.
Höfer, H., C. Martius, W. Hanagarth, M. Garcia, E. Franklin, J. Römbke, and L. Beck. 2000. Soil fauna and litter decomposition in primary and secondary forests and a mixed culture system in Amazonia. 299 p. Final report of SHIFT project ENV 52. BMBF, Bonn, Germany.

Isaac, S.R., and M.A. Nair. 2005. Biodegradation of leaf litter in the warm humid tropics of Kerala, India. Soil Biol. Biochem. 37:1656-1664.

Johansson, M.B., B. Berg, and V. Meentemeyer. 1995. Litter mass-loss rates in late stages of decomposition in a climatic transept of pine forests. Long-term decomposition in a Scots pine forest. Can. J. Bot. 73:1509-1521.

Kurzatkowski, D., C. Martius, H. Höfer, M. Garcia, B. Förster, L. Beck, and P. Vlek. 2004. Litter decomposition, microbial biomass and activity of soil organisms in three agroforestry sites in central Amazonia. Nutr. Cycl. Agroecosyst. 69:257-267.

Lähdesmäki, P., and R. Piispanen. 1988. Degradation products and the hydrolytic enzyme activities in the soil humification processes. Soil Biol. Biochem. 20:287-292.

Leblanc, H.A., P. Nygren, and R.L. McGraw. 2006. Green mulch decomposition and nitrogen release from leaves of two Inga spp. in an organic alley-cropping practice in the humid tropics. Soil Biol. Biochem. 38:349-358.

Liu, P., J. Huang, X. Han, O.J. Sun, and Z. Zhou. 2006. Differential responses of litter decomposition to increased soil nutrients and water between two contrasting grassland plant species of Inner Mongolia, China. Appl. Soil Ecol. 34:266-275.

Mamilov, A.S., and O.M. Dilly. 2002. Soil microbial ecophysiology as affected by short-term variations in environmental conditions. Soil Biol. Biochem. 34:1283-1290.

Musvoto, C., B.M. Campbell, and H. Kirchmann. 2000. Decomposition and nutrient release from mango and miombo woodland litter in Zimbabwe. Soil Biol. Biochem. 32:1111-1119.

Rezende, L.A., L.C. Assis, and E. Nahas. 2004. Carbon, nitrogen and phosphorus mineralization in two soils amended with distillery yeast. Biores. Technol. 94:159-167.

Rezende, J.L.P., Q.S. Garcia, and M.R.M.M.L. Scotti. 2001. Laboratory decomposition of Dalbergia nigra All. ex. Benth. and Eucalyptus grandis W. Hill ex. Maiden leaves in forest and eucalypt plantation soils. Acta Bot. Bras. 15:305-312.

Rigobelo, E.C., and E. Nahas. 2004. Seasonal fluctuations of bacterial population and microbial activity in soils cultivated with Eucalyptus and Pinus. Sci. Agric. (Piracicaba, Braz.) 61:88-93. 
Salamanca, E.F., N. Kaneko, and S. Katagiri. 2003. Rainfall manipulation effects on litter decomposition and the microbial biomass of the forest floor. Appl. Soil Ecol. 22:271-281.

Sall, S.N., D. Masse, N.Y.B. Ndour, and J.L. Chotte. 2006. Does cropping modify the decomposition function and the diversity of the soil microbial community of tropical fallow soil? Appl. Soil Ecol. 31:211-219.

Santa Regina, I., and T. Tarazona. 2001. Nutrient pools to the soil through organic matter and through fall under a Scots pine plantation in the Sierra de la Demanda, Spain. Eur. J. Soil Biol. 37:125-133.

SAS Institute. 1990. Statistical analysis system, SAS/ STAT user's guide. Version 6. 3rd ed. 705 p. SAS Institute, Cary, North Carolina, USA.

Silva, A.C., A.R. dos Santos, e A.V. de Paiva. 1998. Translocação de nutrientes em folhas de Hevea brasiliensis (clone) e em acículas de Pinus oocarpa. R. Un. Alfenas 4:11-18.

Schroth, G., W. Zech, and G. Heimann. 1992. Mulch decomposition under agroforestry conditions in a subhumid tropical savanna processes and influence of perennial plants. Plant Soil 147:1-11.

Summerel, B.A., and L.W. Burgess. 1989. Decomposition and chemical composition of cereal straw. Soil Biol. Biochem. 21:551-559.
Torres, P.A., A.B. Abril, and E.H. Bucher. 2005. Microbial succession in litter decomposition in the semi-arid Chaco woodland. Soil Biol. Biochem. 37:49-54.

USDA. 1975. Department of Agriculture. Soil taxonomy: a basic system of soil classification for making and interpreting soil surveys. 756 p. Agriculture Handbook 436. USDA, Washington DC, USA.

Van Soest, P.J., and R.H. Wine. 1968. The determination of lignin and cellulose in acid-detergent fiber with permanganate. J. Assoc. Off. Agric. Chem. 51:780785.

Virzo De Santo, A., B. Berg, F.A. Rutigliano, A. Alfani, and A. Fioretto. 1993. Factors regulating early-stage decomposition of needle litters in five different coniferous forests. Soil Biol. Biochem. 25:1423-1433.

Waldrop, M.P., D.R. Zak, and R.L. Sinsabaugh. 2004. Microbial community response to nitrogen deposition in northern forest ecosystems. Soil Biol. Biochem. 36:1443-1451.

Wedderburn, M.E., and J. Carter. 1999. Litter decomposition by four functional tree types for use in silvopastoral systems. Soil Biol. Biochem. 31:455461. 